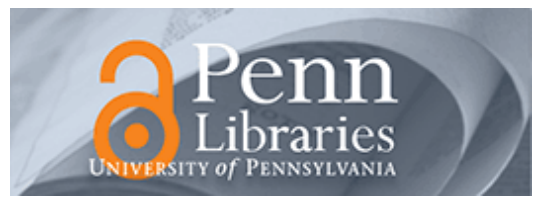

University of Pennsylvania

ScholarlyCommons

Management Papers

Wharton Faculty Research

2010

\title{
The Global Crisis of 2007-2009: Markets, Politics, and Organizations
}

Mauro F. Guillén

University of Pennsylvania

Sandra L. Suárez

Follow this and additional works at: https://repository.upenn.edu/mgmt_papers

Part of the Business Administration, Management, and Operations Commons, Organizational Behavior and Theory Commons, and the Other Business Commons

\section{Recommended Citation}

Guillén, M. F., \& Suárez, S. L. (2010). The Global Crisis of 2007-2009: Markets, Politics, and Organizations. Research in the Sociology of Organizations, 30 (A), 257-279. http://dx.doi.org/10.1108/

S0733-558X(2010)000030A012

This paper is posted at ScholarlyCommons. https://repository.upenn.edu/mgmt_papers/5

For more information, please contact repository@pobox.upenn.edu. 


\title{
The Global Crisis of 2007-2009: Markets, Politics, and Organizations
}

\author{
Abstract \\ In this article, we examine the different causal chains leading to the crisis in the United States and around \\ the world, emphasizing the market developments, political decisions, and organizational factors that led \\ to the financial and economic meltdown. We argue that a series of political, regulatory, and organizational \\ decisions and events prepared the ground for a major breakdown of financial and economic institutions, a \\ "normal accident" that produced systemic reverberations across markets around the world. In the United \\ States, political, regulatory, and organizational decisions made during the 1990 s led to a situation of \\ simultaneously high complexity and tight coupling in the financial system. The global economy also \\ became more complex and tightly coupled during the 1990s, contributing to the rapid spread of the crisis \\ across countries. We propose that solutions to the crisis will need to be tailored to the specific ways in \\ which countries experienced the meltdown and the political preferences of interest groups and citizens. \\ For the United States, the best approach would be to allow for a complex and innovative financial system \\ but with a much reduced degree of coupling so as to avoid another financial normal accident. \\ Disciplines \\ Business Administration, Management, and Operations | Organizational Behavior and Theory | Other \\ Business
}


THE GLOBAL CRISIS OF 2007-2009:

MARKETS, POLITICS, AND ORGANIZATIONS

\author{
Mauro F. Guillén \\ The Lauder Institute \\ The Wharton School \\ University of Pennsylvania \\ and \\ Sandra L. Suárez \\ Department of Political Science \\ Temple University \\ September 2009 Version
}

Send all correspondence to: guillen@wharton.upenn.edu 


\begin{abstract}
In this paper we examine the different causal chains leading to the crisis in the U.S. and around the world, emphasizing the market developments, political decisions, and organizational factors that led to the financial and economic meltdown. We argue that a series of political, regulatory and organizational decisions and events prepared the ground for a major breakdown of financial and economic institutions. In the United States, these decisions led to a situation of simultaneously high complexity and tight coupling in the financial system. We propose that solutions to the crisis will need to be tailored to the specific ways in which countries experienced the meltdown and the political preferences of interest groups and citizens. For the U.S., the best approach would be to allow for a complex and innovative financial system but with a much reduced degree of coupling.
\end{abstract}


On February 7, 2007 one of the world's largest banks, HSBC, announced losses related to U.S. subprime mortgage loans. A couple of months later, on April 3, New Century Financial, a subprime specialist, filed for Chapter 11 bankruptcy. In June, Bear Stearns told an incredulous financial community that two of its hedge funds suffered large losses related to subprime mortgages. Other Wall Street standard-bearers also started reeling from bad investments, including Merrill Lynch, JPMorgan Chase, Citigroup and Goldman Sachs. Before the end of August the crisis had spread to some French and German banks, and prompted the Federal Reserve and the European Central Bank to pump liquidity into the banking system and to reconsider their interest-rate policies.

These were only the beginnings of a truly global financial and economic crisis that marked the end of one of the greatest financial expansions in history. The recession officially started in December 2007. By mid 2009, the crisis had brought to their knees major bank and non-bank financial institutions, causing several to collapse, and led to a severe economic contraction, plummeting trade, rising unemployment, and price deflation. The crisis quickly acquired global proportions after hitting Western and Eastern Europe, Japan, Latin America, and the rest of Asia.

\section{The Crisis in the United States}

The causes of the crisis in the United States are diverse and difficult to untangle. At the core lies the problem of asset price inflation, especially in the stock and housing markets. With the benefit of hindsight, we know that the bubbles were largely the result of unusually low interest rates between 2001 and 2006. The Federal Reserve could have curbed asset-price inflation, but its attention was focused on sustaining the economic recovery. It ignored other signs of economic stress and risky behavior by financial institutions. In particular, Chairman Alan Greenspan was not as technocratic and independent as everyone assumed. In fact, he behaved in a rather charismatic way since the early 2000s, becoming a larger public figure than the venerable institution he chaired. Most importantly, it appears that he preferred to downplay the first signs of trouble so as to avoid raising interest rates during the months leading to the 2004 Presidential Election, in a reversal of his policy stand in 1992, when he was accused of undermining George H. W. Bush's reelection chances. Loose monetary policy was, in many ways, a first important background factor leading to the crisis.

A second contributing factor had to do with recent developments in emerging economies, especially China. During the 1990s, emerging economies had witnessed or experienced firsthand what could happen to them in the event of a currency or a sovereign debt crisis, or both. Between 1997 and 1999 several East Asian economies, Brazil and Russia fell like dominos to the pressures of short-term capital outflows and currency speculators. The International Monetary Fund (IMF) stepped in to provide liquidity, but with strings attached, including wide-ranging institutional reforms. These "conditionality" clauses became the source of major debates among economists and produced a backlash in emerging economies against the coercive practices of the IMF. In many cases, the policies and reforms mandated by the IMF proved counterproductive (Guillén 2001:190-197; Henisz et al. 2005). China, in particular, took good note of the situation. 
It embarked on a frenetic policy of amassing foreign reserves and investing them in securities issued by foreign governments, especially the United States. According to IMF (2009b) data, during 2008 China accounted for 24 percent of all capital exports in the world, and the United States for 43 percent of all imports. Other big exporters included Germany (nearly 13 percent), Japan (9), Saudi Arabia (8), and Russia (6). After the United States, the largest recipients were Spain (10 percent of the world's total), Italy (5), and Greece (3). Thus, the world of international capital flows had become polarized between the exporters and the importers, with China and the United States playing the leading roles, respectively. Massive inflows of cheap money from abroad helped keep interest rates low, thus fuelling the twin asset-price bubbles. One way to reduce the imbalances between the U.S. and China would be for the latter to allow its currency to float, something that Beijing continues to resist since it would reduce the competitiveness of its exports.

The crisis, however, would not have reached such massive proportions without the peculiar, and to a large extent unprecedented, developments taking place in the financial sector. Financial institutions, both bank and non-bank, felt strong pressures to meet growth and profit expectations in order to prop up their share price. This aspect, in and of itself, was not unique to financial services. Corporations across the board were under intense pressure to increase performance, especially at a time when shareholder wealth maximization dominated debates about corporate governance (Davis 2009). Low interest rates, however, affected financial and non-financial companies in sharply different ways. A manufacturing firm usually benefits from low rates because it can more cheaply fund its needs for working and fixed capital, and its customers also see their credit possibilities improve. By contrast, low rates tend to constrain the ability of banks to make a profit because when rates are low, spreads are minuscule.

And yet, financial industry profits grew during the 2000s from representing no more than 20 percent of all U.S. corporate profits to more than 40 percent. During 2007, on the eve of the crisis, 41 percent of all corporate profits were accounted for by the financial services industry, at a time when it represented about 15 percent of economic activity, as measured by gross value added. These massive profits could not possibly have come from interest rate spreads. Rather, they came from leverage and from fees and commissions collected through the design and sale of new financial products. While non-financial corporations and the government barely increased their leverage, households and, especially, financial institutions did so at a staggering rate. According to the IMF (2009a), by the end of 2007 financial institutions had trebled their leverage when compared to the late 1990s.

At the core of the quest to generate shareholder wealth in financial services through leverage and new financial products were a series of perverse incentives. Bonuses were perhaps the most blatant, especially when they were tied to revenue growth and not profits, or when the financial company could generate fees and commissions but not be responsible for the risk attached to the products. Concerning top management, stock grants were especially pernicious, as they would perversely reinforce risky behavior so as to meet Wall Street's expectations. Competition for the best traders also proved problematic because they were showered with incentives based on shortterm performance, which invited risky behavior as well. Moreover, when compensated in stock, executives and traders borrowed against it in order to maintain a lavish lifestyle. Their own leveraged finances as individuals added to the desire to meet revenue and profit expectations. 
Another growing incentive-related problem concerned conflict of interest. Large, diversified financial institutions became fond of playing multiple, conflicting roles. For instance, one division would advise a client issuing securities while another would sell the securities to investors. The CEO office at some of the banks obviously saw this questionable practice as a sure way to grow revenue.

Moral hazards are another oft-mentioned cause of the crisis. There is some evidence indicating that the CEOs of financial institutions came to the realization that the government would not let them collapse. This sense of being ultimately backed up by the taxpayer was probably reinforced by the 1998 bailout of Long Term Capital Management.

Ignorance or irresponsibility about the costs of risky behavior afflicted not only financial institutions but individual citizens as well. Just like financial institutions, U.S. consumers lured by lower interest rates and the belief that housing prices would never go down became highly leveraged. When the economy is healthy, borrowing allows individuals to share in the relative prosperity and boost their consumption, but it also makes households more vulnerable to changes in interest rates and disposable income. In turn, increases in mortgage delinquency and foreclosures further contributed to the losses of financial institutions. Since the 1980s household debt as a percentage of disposable income had increased to over 100 percent in many developed countries. By 2005, household leverage was 159 percent in U.K, 135 in the U.S., 141 in Ireland, and 107 in Spain and Germany. Leveraged households do not always pose a potential problem. During the 1980s and 90s, the majority of household debt was held by higher-income families with the means to pay it down. The pressure for profits and the relaxation of financing rules, however, allowed credit to be extended to households with a much smaller capacity to pay it back, especially if interest rates on the loans reset to higher levels (Girouard et. al. 2007).

Initially the concept of debt securitization and the slicing of mortgages was thought to shield financial institutions from the risk of extending credit to subprime borrowers. But as debt securitization became more popular, the risk actually became more concentrated within U.S. banks. We now know that most holders of securitized debt were highly leveraged financial institutions.

Finally, the financial crisis of 2007-2009 has brought to the surface the massive information asymmetries among the various actors involved in the activities of complex financial institutions, including top executives, traders, directors, shareholders, bondholders, raters, insurers, regulators, and so on. Clearly, employees were not telling top executives every detail of their doings, as the bizarre episode of renegade trader Jérôme Kerviel at the French bank Société Générale illustrates. Top executives, whether out of ignorance or not, failed to give directors a clear picture of the situation. Shareholders and bondholders were in the dark, in part because raters and insurers were saying that everything was fine. And even as rating agencies began issuing downgrades and subprime delinquencies started to spike, the IMF (2007) reported that financial institutions were "sufficiently capitalized, diversified and profitable to absorb direct losses." Regulators, for reasons to be analyzed later, were even more in the dark due to their lack of resources and the fragmentation of the regulatory structure. 


\section{Financial Innovations}

Innovation lies at the heart of the capitalist economy. Financial innovations, however, are peculiar because it is very difficult to protect them from imitation by competitors. Financial institutions quickly learned that innovations such as derivatives could be the source of sustainable profits if new products or structures were constantly designed, new types of underlying assets became available as raw material, technology or expertise barriers could be created, mass production were possible, and at least some of them could be taken off the books in order to maximize the use of the capital base. The early successes of JP Morgan and Goldman Sachs in derivative innovation attracted myriad imitators, including commercial and investment banks and insurance companies, both domestic and foreign. A key issue in this respect was that the imitators often misunderstood the risks and the limits of the innovations (Tett 2009).

The most important innovation in securitization was collateralized debt obligations (CDOs). In essence, you would put a large number of income-generating assets such as bonds, mortgages or other types of debt into a pool and then issue securities for sale to investors. CDOs could also be made from other CDOs, and they were called CDOs squared. Yet another type was synthetic CDOs, made from credit derivatives. The issues with CDOs and other securitizations were threefold. First, originators cared about volume, not quality. Second, in order to calculate the risk you would need to have historical data on how the underlying assets performed over several business cycles. This was certainly possible with bonds issued by major corporations, but not with residential mortgages, simply because there had never been a truly devastating mortgage crisis in the past and the quality of many of the new borrowers was unknown. In general, default probabilities for CDOs were grossly underestimated. Also, increasingly complex and unreliable computer models had to be used in order to calculate default probabilities when the underlying assets were sliced and diced multiple times. And third, in order to maximize profits, originators needed to mass produce the securities, move assets off balance to free up capital, and obtain the highest possible rating for a given return level. Among other tactics, they engaged in "ratings arbitrage," whereby originators exploited loopholes in the rating agencies' computer models.

Credit derivatives were the other important financial innovation, and the one that brought AIG down, at a cost of $\$ 180$ billion to taxpayers. In the classic credit default swap (CDS), the buyer makes a periodic payment and receives a payoff from the seller if an underlying debt instrument such as a loan or bond defaults. CDSs have certain peculiarities that are important to note. First, the buyer need not own the underlying instrument. Second, the seller need neither be a regulated insurer nor set aside enough capital to cover potential losses. Third, the seller often misunderstood the risk inherent to the underlying instrument. And fourth, the buyer might be fooled by a false sense of security and take on more risk, thus exacerbating moral hazard.

The mounting pile of mortgage debt from the credit expansion of the 2000s provided excellent raw material for derivatives. Subprime loans were especially attractive to originators because of their high interest rates; all they needed to do was persuade the rating agencies and the investors that the slicing and dicing reduced the risk while preserving the return. Moreover, CDOs and CDSs were over-the-counter instruments, meaning that there was no central clearinghouse or market. The result was a lack of transparency concerning the risk-return profile of the innovative products. 


\section{Manifestations of the Crisis}

The causes of the crisis should not be confused with the symptoms of financial and economic distress that became readily apparent since the summer of 2007. The first indications of the trouble lying ahead came from the fact that banks in the U.S. and Europe stopped trusting each other because of the lack of reliable information as to the solvency of even the most prominent financial institutions. Interbank lending is a large-scale activity, one that keeps the financial sector going. It essentially collapsed during the summer of 2007 as banks hoarded cash. Beginning in the fall of 2007, banks made far fewer loans, causing a rapid contraction in credit flows to the private sector.

The interrelated liquidity and credit crunches started to affect the real economy shortly thereafter. Real-estate prices and new-home construction dropped rapidly, consumer confidence and retail sales plummeted as people postponed or cancelled non-essential purchases, GDP growth decreased and even turned negative in several economies, including the U.S., which officially declared that the recession started in December of 2007; unemployment soared (IMF 2009b).

\section{The Crisis as a Normal Accident}

From an organizational point of view, the financial crisis of 2007-2009 is a rather unique event because it exhibits the two key characteristics of a "normal accident." This is a situation in which a system fails because it is simultaneously complex (as opposed to linear) and tightly coupled (as opposed to loosely coupled). These two dimensions are displayed in Table 1. A system is complex when there are many non-linear interconnections and the specialization of its subcomponents prevents actors from gaining an understanding of the overall system. A system is tightly coupled when delays are not possible, there is no slack, and there are no buffers or redundancies built into it (Perrow 1984:88, 96). Normal accidents are catastrophes waiting to happen due to the combination of high complexity and extreme tight coupling.

Since the late 1990s, the financial system of the United States became both far more complex and more tightly coupled than in the past, and thus prone to a normal accident. Its increasing complexity stemmed from the rise of large, diversified financial institutions, often with operations spanning the globe (see point 1 in Table 2). These organizations created specialized entities to pursue new products and markets. In many cases they located the divisions far away from corporate headquarters, in places friendly to innovation. This was the case for JP Morgan, Lehman Brothers, and AIG, whose financial products divisions were located in London, taking advantage of less restrictive regulations. These divisions operated with a high degree of autonomy, and often without direct supervision from the CEO's office thousands of miles away. They innovated in new financial products involving securitization of certain income-producing assets (CDOs) and credit derivatives (CDSs). The so-called quants developed the products and the computer models to price them, while the managers made the decisions as to how to allocate billions of dollars across different products and activities. This specialization of roles meant that 
nobody had a coherent view of the rising complexity of the overall set of activities in which each financial institution was engaged in.

The new products had a number of characteristics that increased complexity (point 2 in Table 2). They exposed a large number of financial institutions to risks that they didnot fully understand because the underlying assets were sliced and diced multiple times (Tett 2009). While the innovators had a reasonably good understanding of the characteristics and risks of the new products, the imitators did not. Another tricky aspect was that profitability depended on charging fees and commissions, which encouraged mass production and selling the products quickly to other market participants, further complicating risk assessment. Moreover, newly developed models and techniques such as the Gaussian copula function were used since approximately 2000 by Wall Street to calculate CDO risks based on CDS prices instead of historical default data, under the assumption that the market was pricing correctly (Salmon 2009). As of December 2007 there were 3 to 4 trillion dollars worth of outstanding CDOs, and a staggering 35 to 45 trillion of CDSs. Literally, millions of counterparties were involved in an exceedingly complex web of interconnections. When Lehman went bankrupt in September 2008, for instance, more than 700,000 counterparties were affected.

In addition to its increasing complexity, the U.S. financial system also became far more tightly coupled than in the past. This was due to two key causes. First, financial institutions increased their leverage in order to extract the highest possible returns from their capital base, thus reducing the slack in the system (point 3 in Table 2). Increased leverage reduced the buffer against adverse events or wrong bets, thus making the system more rigid, i.e. more tightly coupled. Financial institutions simply found it hard to absorb shocks or unexpected events because they lacked an appropriate capital base to cope with unforeseen deviations in the performance of their supposedly finely-tuned bets and investments.

Second, the new securities and credit derivatives were mostly tailor-made for specific buyers, and transacted over the counter (OTC), i.e. there was no clearinghouse or market for them (point 4 in Table 2). This meant that it was difficult to exit investments when conditions took a turn for the worse. Not surprisingly, one of the earliest symptoms of the gravity of the crisis had to do with the inability of banks to price the products in their portfolios. This was due to the lack of a market for transacting them. The twin problems caused by the lack of a clearinghouse or market, and excessive leverage became exacerbated with the liquidity crunch that started in the summer of 2007. In a related event, the collapse of the commercial paper market also wreaked havoc with another innovation, structured investment vehicles (SIVs). They had been pioneered by Citigroup in the late 1980s. These funds made money by issuing short-term securities at relatively low interest rates and lending the proceeds in the form of long-term securities at higher rates, some of them asset-backed. In the summer and fall of 2007 Bank of America and Northern Rock, the British bank, both suffered substantial losses from SIVs essentially because they managed themselves into a corner of the financial system that was so tightly coupled that a disruption in the rollover scheme produced billions of dollars in losses.

Although not new, another factor that contributed to the tight coupling of the financial system was advances in computer technology. During the crash of 1987, known as "Black Monday," the U.S. stock market suffered a one day decline of 22.6 percent, the largest since 1914. Another 
sudden drop occurred in 1997, know as "Black Friday." On both occasions, program trading was seen as a factor. Program trading occurs when computer models determine the time to execute buy and sell orders. With the advent of what is referred to as "high frequency program trading," the trade occurs in nanoseconds. Program trading makes the markets highly interconnected as it enables financial institutions to profit from small discrepancies in price across exchanges. It can also trigger a domino effect that results in wild swings during a single day. In the U.S. exchanges estimate that between 30 and 50 percent of all of their trades are executed by a small group of high-frequency traders, among them Goldman Sachs. The month of October 2008 saw "Bloody Friday," and several markets halted trading after experiencing some of their worst downturns on record. Program trading likely played a role in the unfolding of the crisis that needs to be further investigated. Faster computers and the 2000 switch from eighths and sixteenths of a dollar to decimal pricing likely increased the coupling of financial markets. Estimates indicate that between 30 and 50 percent of all share transactions are high-frequency trades (Economist 2009).

The U.S. financial system might have withstood the bursting of the real-estate bubble and the subprime meltdown if financial companies had been less leveraged and a clearinghouse or market had been available, that is, if the system-however complex-were not as tightly coupled as it was. After years of daring financial innovations and rising financial leverage, the system lacked appropriate cushions and buffers. When trust among financial institutions evaporated in the summer and fall of 2007, the liquidity crunch pushed this tightly-coupled system to the brink of collapse. Only massive liquidity and capital injections by the Fed, the European Central Bank, and other central banks prevented a catastrophe. It was the combination of rising complexity and tight coupling that produced a normal accident of epic proportions, one that required hundreds of billions of dollars to repair and transformed the industry for years to come.

\section{The Politics of Fragmented Regulation}

The rapidly changing regulatory landscape of the 1990s and 2000s contributed to the financial meltdown by allowing - even encouraging - the system to become more complex and tightly coupled (point 5 in Table 2). The overall trend since the 1980s was one of removal of obstacles to the free unfolding of market forces and to the introduction of sophisticated financial innovations, under the assumption that markets could self-regulate. In 1986, Margaret Thatcher set into motion a major revolution in financial services with the so-called London Big Bang. This reform should be seen in the context of a package of "neo-liberal" reforms (Babb and FourcadeGourinchas 2002). Fixed trading commissions were eliminated, electronic trading introduced, and the cozy club of City insiders was effectively dismantled. Over the next two decades, London regained its long-gone status as a global financial center, attracting the likes of JP Morgan, Lehman and AIG. The fact that regulatory oversight was less stringent in London made it a magnet for U.S. financial institutions as a location in which to experiment with new financial products.

Meanwhile, regulatory developments in the U.S. were creating a more fertile ground for financial innovation and risk taking, and making the financial system both more complex and more tightly coupled. In the early 1990s regulators and Congress considered several initiatives and bills to monitor and oversee the expanding universe of derivatives. Intense industry lobbying caused 
these initiatives to be shelved. In 1996 the Fed made the astonishing decision to allow financial institutions to reduce required reserves if they used credit derivatives to curb risks. Perhaps the most prominent piece of legislation from the 1990s was the Financial Services Modernization Act of 1999, which repealed the even more famous Glass-Steagall Act of 1933. Banks, securities firms and insurance companies could now compete with each other. Then Treasury Secretary Lawrence Summers explained that "at the end of the $20^{\text {th }}$ century we will at last be replacing an archaic set of restrictions [on financial activity] with a legislative foundation for a $21^{\text {st }}$ century financial system." He asserted that the legislation "would provide significant benefits to the national economy" (as quoted in Labaton 1999).

The removal of restrictions per se did not necessarily have to spell trouble. After all, many countries around the world allowed integrated and diversified financial firms to operate. Unlike in other countries, however, the U.S. regulatory structure was not overhauled in order to guarantee the stability of this radically changed financial system. Commercial banks continued to be supervised by the Federal Reserve, the Office of the Comptroller of the Currency, the FDIC and individual states. Securities firms were primarily under the watch of the Securities and Exchange Commission (SEC). Insurance companies were regulated by individual states and by the Department of Labor. After 1999, a diversified financial services company was allowed to choose the regulator for each of its businesses, leading to a situation in which no single government body had a 360-degree view of the entire portfolio of each company and the associated systemic interactions. The Commodity Futures Modernization Act of 2000 also added to the problem by treating swaps as distinct from futures or securities. This essentially meant that neither the SEC nor the Commodity Futures Trading Commission (which is overseen by the U.S. Congress Agriculture committee!) could supervise these new, and potentially lethal, financial products. Industry lobbying was very effective at obtaining a favorable ruling on the part of the SEC concerning leverage ratios. In 2004 the agency voted to raise them. Not surprisingly, Lehman, Bear Stearns and Morgan Stanley increased their asset-to-equity ratios above 3,000 percent, and Merrill Lynch and Goldman Sachs to above 2,500 percent.

The case of AIG, by far the largest and most costly bailout to date, illustrates the effects of deregulation and fragmented supervision. Before the end of 1999, the ink on the Modernization Act still fresh, AIG acquired the status of thrift holding company, when the Office of Thrift Supervision (OTS) approved its application to charter AIG Bank. It also received approval to buy a small savings \& loans bank in Delaware. The OTS had been created in the wake of the savings \& loans crisis to replace the Federal Home Loan Bank Board, and had virtually no expertise in credit derivatives. Still, AIG's infamous financial products division (based in London), as well as the thrifts at General Motors, General Electric and some divisions of Lehman Brothers, Merrill Lynch, and Morgan Stanley came under the supervision of the OTS, primarily because these firms chose it as the regulator. After lobbying European regulators, the OTS was conferred equivalency for supervising AIG between 2004 and 2007, which meant that it was the only agency supervising the company's London operation and its growing portfolio of derivatives, which eventually reached 1.5 trillion dollars (Gerth 2008). In early 2007 the Government Accountability Office issued a bruising report documenting the lack of expertise at several of the regulatory agencies, including OTS, when it came to supervising derivative products (GAO 2007). On 3 March 2009, Ben Bernanke summarized the situation at a Senate 
Hearing when he stated that AIG "exploited a huge gap in the regulatory system" and that "there was no oversight of the [AIG] Financial Products division" (Gerth 2008).

\section{Global Spread}

One of the key characteristics of the crisis has been its rapid spread around the world in terms of reduced economic growth and rising unemployment. In most countries, the causal chain leading to financial and economic problems did not primarily involve a direct impact from U.S. toxic financial products, although some banks in Germany and Switzerland reported heavy subprime losses as early as August and October 2007, respectively. In the United Kingdom and Ireland, the causal chain started, like in the U.S., with the bursting of the domestic real-estate bubble infecting the financial sector and it in turn bringing about a severe economic recession.

In a second group of countries, the problems started in the financial sector and then spilled over into the real economy. In the dramatic case of Iceland, the problems originated in bad financial investments and cross-border arbitrage bets. In Switzerland, bad financial investments by UBS and other banks (and falling trade volumes) hit the real economy hard. In most Eastern European countries, growth was based on foreign borrowing, which largely evaporated as a result of the global financial turmoil. The ensuing credit contraction brought these economies to a standstill. Persistent currency depreciations made matters worse in Hungary, Poland and the Czech Republic. Meanwhile, countries with fixed exchange rates (Bulgaria, the Baltics) run the risk of a sudden devaluation.

A third causal chain started with a drastic fall in construction and real-estate activity that infected the real economy, and could potentially affect the financial sector (e.g. Spain, Dubai).

Construction had been a major engine of economic growth and employment in both countries. The quick reversal of fortune in that sector spilled over into the real economy very fast, causing growth to slow down and unemployment to soar. These countries also suffered from lower tourist arrivals and in Dubai's case, reduced global trade. Depending on how long and deep the recession proves to be, the financial systems of these countries could be severely affected.

A fourth chain involved the decline in trade and its devastating effects on industrial production and employment in export-oriented economies such as China, Mexico, Japan, Germany, and, as noted above, Switzerland. The smaller, export-oriented Eastern European countries also suffered from the decline in trade. Finally, exporters of commodities were hurt by the sudden drop in prices, including Russia and several Middle Eastern, South American and African countries, as well as Canada and Australia.

These causal chains indicate that the crisis diffused from the U.S. to export-oriented economies through the trade channel, especially in a situation in which proportionally speaking more trade is destroyed as GDP growth slows down as a result of the off-shoring of so many business functions and intermediate goods. A second group of countries experienced economic difficulties when their domestic construction, real-estate and/or financial sectors got into trouble. Very few countries have been directly and significantly affected by U.S. toxic financial products. As the 
IMF recently noted, "the United States is grappling with the financial core of the crisis" (IMF 2009b:63).

\section{The Search for Solutions: Ideology and Politics}

Government officials and central bankers responded with different degrees of urgency to the crisis, due not only to the lags in its spread around the world but also because of the different ways in which each country entered the crisis, political preferences and ideologies, and the power of interest groups. Most of the early policy responses had to do with a strategy of containment, especially in terms of interest rate reductions, emergency liquidity support, and enhanced guarantees for bank deposits. These measures sought to provide the buffers and cushions that the tightly coupled financial system lacked. Other more extreme measures, like a suspension of the convertibility of bank deposits and regulatory capital forbearance, were avoided for their politically costly or even counterproductive effects, although they had been used in other recent banking crises around the world (Laeven and Valencia 2008).

Policymakers then turned to resolution strategies. The repertoire of potential measures included workout programs of bad loans, government insurance of bad debt, the transfer of bad debts to a government asset management company (a "bad bank"), sales of financial institutions to new owners, government intervention and recapitalization of banks, and bank liquidations (Laeven and Valencia 2008). In the two large countries with the most severely damaged financial systems - the U.S. and the U.K. - the government and the central bank followed different approaches. In the U.K., the government moved swiftly to nationalize the first victim (Northern Rock) in February of 2008, and other smaller institutions, including Bradford \& Bingley, and major recapitalizations through state ownership of the country's major banks, such as Lloyds and Royal Bank of Scotland. By contrast, U.S. policymakers engaged in a haphazard series of actions, in part driven by the pressures from the banks themselves, and by the difficulty of selling to the Congress and the public massive government intervention in the financial sector.

Thus, during the crucial year of 2008, U.S. policymakers implemented a breadth-taking variety of responses: in March they orchestrated the takeover of Bear Stearns by JP Morgan; in July regulators seized IndyMac; in September mortgage giants Freddie Mac and Fannie Mae were brought under government conservatorship; in September Lehman Brothers was let go bankrupt, in a decision that sent the markets into a tailspin; shortly thereafter, a lifeline was established for AIG, Bank of America took over Merrill Lynch, JP Morgan acquired Washington Mutual, and Citigroup was slated to purchase Wachovia, although Wells Fargo finally got the prize a month later; in early October Congress passed a $\$ 700$ billion Troubled Assets Relief Program (TARP), subsequently used to recapitalize Citibank ( $\$ 25$ billion), JP Morgan Chase (25), Bank of America (20), Wells Fargo (20), and, after converting themselves into bank holding companies, Goldman Sachs (10) and Morgan Stanley (10); in November AIG became practically owned by the government while Citigroup received a lifeline potentially worth $\$ 306$ billion and a further capital injection of $\$ 20$ billion, leaving the government with a one-third equity stake; and in December GM and Chrysler received approval for bailout funds of up to $\$ 18$ billion. The Obama Administration, for its part, passed through Congress a stimulus packet worth $\$ 787$ billion and a 
modified Troubled Asset Relief Program (known as TARP II), whose implementation had not yet started at the time of writing.

Other countries have not had to deal with massive problems in the financial sector, but with a major economic downturn or the potential for one. As a result, they have not engaged in major financial bailouts and reengineering, but in fiscal stimulus to prop up the real economy. A noteworthy case is China, which approved a vast stimulus packet worth 5.5 percent of GDP in 2009 and 6.5 percent in 2010, three times larger than the U.S. stimulus. India also announced a similarly large packet. In both cases, up to 90 percent of the money will be spent on physical infrastructure projects, whereas in the U.S. only 10 percent will, with the rest going into tax credits for families, education, science \& technology, renewable energy, Medicaid, unemployment benefits, and healthcare information technologies. Clearly, the political processrather than the counter-cyclical impact of the spending - shaped the allocation of funds. Europe appears to be divided, also for ideological and political reasons. The U.K. approved a fiscal stimulus as big as the U.S.'s relative to the size of the economy, and France has implemented an infrastructure program, but Germany has been much more reluctant to spend its way out of the recession. For historical and ideological reasons, the Germans can live with high unemployment but want to avoid inflation at all costs, while the French have the reverse preferences.

Meanwhile, researchers at the IMF have demonstrated that a coordinated global stimulus would be somewhat more effective at turning the global economy around than individual efforts by different countries, in large measure because the spending from any stimulus packet leaks or spills over into other countries due to trade and other interconnections (Freedman et al. 2009).

\section{Concluding Thoughts}

It is perhaps too early to draw any definitive conclusions about the causes of the crisis, the effectiveness of the policy solutions to contain and resolve it, and the best ways to prevent a similar meltdown in the future. Regarding the causes, we have emphasized contextual factors such as monetary policy and global imbalances, and organizational dynamics such as profit maximization, perverse incentives, and financial innovations. These arguments apply to the case of the U.S., and partly to the U.K. In other countries, the crisis started and grew in different ways. Policy solutions have been driven by ideology and interest-group pressures as much as by purely economic or technical considerations.

The trickiest issue of all is how to think about preventive measures. Most experts and observers have proclaimed the need for more regulation. In the U.S., this is a somewhat stigmatized term, although the political and ideological tide seems to be turning in favor of more comprehensive supervision and oversight. Based on the analysis of the U.S. financial crisis as a normal accident, there are two options that strike a balance between effective regulation and oversight, on the one hand, and financial dynamism and innovation, on the other. The first is to allow diversified financial institutions to grow and innovate in financial products, but forcing them to reduce their leverage and to agree to the creation of a transparent market for derivative products. Essentially, this option entails keeping the financial system relatively complex but much less tightly coupled than it became during the last decade or so. The present fragmented regulatory structure in the U.S. would need to be simplified and streamlined so that any potential harmful effects from the 
complexity of the system could be detected and addressed swiftly. In addition, international capital mobility might have to be regulated and monitored (Reinhardt and Rogoff 2008). The second option is to prevent banks and other financial institutions from diversifying and growing too much, fostering innovation among smaller institutions, and permitting higher levels of leverage so that they can be profitable. This second option would reduce the complexity of the system but allow for a relatively higher level of tight coupling.

Naturally, one could propose regulatory preventive measures that reduce both the complexity and the coupling of the U.S. financial system. This third option would come under attack for its potentially draconian impact on financial innovation, and it might encounter heavy opposition from financial interests and some political quarters, leading to a backlash and possible regulatory reversal in the near future. We see the first option-allowing complexity while reducing tight coupling - as the most politically pragmatic and potentially effective way of preventing a future crisis of similar characteristics and scale while keeping the promise of financial innovation alive. 


\section{References}

Davis, Gerald F. 2009. "The Rise and Fall of Finance and the End of the Society of Organizations." Academy of Management Perspectives (August):27-44.

Economist. 2009. "High-Frequency Trading: Rise of the Machines.” The Economist, July 30.

Fourcade-Gourinchas, Marion, and Sarah L. Babb. 2002. "The Rebirth of the Liberal Creed: Paths to Neoliberalism in Four Countries." American Journal of Sociology 108:533-579.

Freedman, Charles, et al. 2009. "The Case for a Global Fiscal Stimulus." IMF Staff Position Note 09/03, issued March 6.

GAO. 2007. Financial Market Regulation: Agencies Engaged in Consolidated Supervision Can Strengthen Performance Measurement and Collaboration. Washington, D.C.: Government Accountability Office, report number GAO-07-154, released March 15, 2007.

Gerth, Jeff. 2008. “Was AIG Watchdog Not Up To The Job?” November 10. www.propublica.org

Girouard N, Kennedy M. and Andre C. 2006. "Has The Rise in Debt Made Households More Vulnerable?” OECD Economics Department Working Paper no. 535, OECD.

Guillén, Mauro F. 2001. The Limits of Convergence. Princeton, NJ: Princeton University Press.

Henisz, Witold J., Bennet A. Zelner, and Mauro F. Guillén. 2005. "Market-Oriented Infrastructure Reforms, 1977-1999.” American Sociological Review 70(6) (December):871-897.

IMF. 2009a. Financial Stability Report. Washington, DC: International Monetary Fund.

IMF. 2009b. World Economic Outlook. Washington, DC: International Monetary Fund.

IMF. 2007. Financial Stability Report. Washington, DC: International Monetary Fund.

Labaton, Stephen. 1999. “A New Financial Era.” The New York Times October 23, section A, p. 1.

Laeven, Luc, and Fabian Valencia. 2008. "Systemic Banking Crises: A New Database." IMF Working Paper 08/224. Washington, DC: International Monetary Fund.

Perrow, Charles. 1984. Normal Accidents: Living with High-Risk Technologies. New York: Basic. 
Reinhardt, Carmen M., and Kenneth S. Rogoff. 2008. “This Time is Different.” NBER WP 13882. Cambridge, MA: National Bureau of Economic Research.

Salmon, Felix. 2009. "Recipe for Disaster: The Formula that Killed Wall Street." Wired Magazine 23 February 2009.

Tett, Gillian. 2009. Fool's Gold: How the Bold Dream of a Small Tribe at J.P. Morgan Was Corrupted by Wall Street Greed and Unleashed a Catastrophe. New York: Free Press. 
Table 1: Four System Configurations in terms of Complexity and Coupling

\begin{tabular}{|c|c|c|}
\hline \multirow{2}{*}{ Complexity: } & \multicolumn{2}{|c|}{ Coupling: } \\
\cline { 2 - 3 } & Loose & Tight \\
\hline High & $\begin{array}{c}\text { Complex interactions } \\
\text { with built-in buffers } \\
\text { There is room to adapt in } \\
\text { response to deviations and } \\
\text { mishaps, even if systemic }\end{array}$ & $\begin{array}{c}\text { Complex interactions } \\
\text { without buffers } \\
\text { Potential for disaster }\end{array}$ \\
\hline Low & $\begin{array}{c}\text { Linear interactions } \\
\text { with built-in buffers } \\
\text { Very easy to manage }\end{array}$ & $\begin{array}{c}\text { Leviations and mishaps not of } \\
\text { without buftemic nature } \\
\text { systers }\end{array}$ \\
& \multicolumn{2}{|c}{} \\
\hline
\end{tabular}

Source: Adapted from Charles Perrow, Normal Accidents: Living with High-Risk Technologies. New York: Basic Books, 1994. 
Table 2: Factors Contributing to the Complexity and Tight Coupling of the Financial System during the 2000s

\begin{tabular}{|c|c|}
\hline Complexity & Tight Coupling \\
\hline $\begin{array}{l}\text { 1. Rise of large, diversified financial } \\
\text { institutions with: } \\
\text { - A high degree of internal organizational } \\
\text { specialization and differentiation, } \\
\text { including new financial product } \\
\text { departments enjoying a high degree of } \\
\text { autonomy. } \\
\text { - An increasing division of roles and } \\
\text { responsibilities (quants, managers, } \\
\text { traders, etc.). } \\
\text { As a consequence, few if any people inside } \\
\text { large, diversified financial institutions had an } \\
\text { overall understanding of the various activities } \\
\text { conducted by separate departments and } \\
\text { individuals. }\end{array}$ & $\begin{array}{l}\text { 3. Leverage: } \\
\text { - Given thin margins, financial leverage } \\
\text { used to squeeze returns from the available } \\
\text { capital base. } \\
\text { As a consequence, financial institutions were } \\
\text { operating close to the edge, with little room for } \\
\text { making corrections, and subject to enormous } \\
\text { pressure if the predicted profits turned into } \\
\text { losses. The liquidity crunch exacerbated this } \\
\text { problem. }\end{array}$ \\
\hline $\begin{array}{l}\text { 2. New financial products (asset-backed } \\
\text { securities, credit-default swaps): } \\
\text { - Given thin margins, mass production is } \\
\text { necessary to generate sizable profits. } \\
\text { - Imitators do not fully understand the } \\
\text { risks. } \\
\text { - Innovators were hard-pressed to design } \\
\text { new products in order to stay ahead of the } \\
\text { imitators. } \\
\text { - Profitability of fees and commissions } \\
\text { resulted in new products changing hands } \\
\text { quickly. } \\
\text { - A tendency to use sophisticated } \\
\text { mathematical models to overcome issues } \\
\text { and difficulties with the pricing of risk, } \\
\text { and to feed the models with derivative } \\
\text { prices as opposed to historical default data. } \\
\text { As a consequence, financial institutions } \\
\text { exposed themselves, and each other, to risks } \\
\text { they did not fully understand and could not } \\
\text { calculate accurately. }\end{array}$ & $\begin{array}{l}\text { 4. Lack of a clearinghouse or market for many } \\
\text { of the new financial products, especially those } \\
\text { tailor-made for specific clients and traded over } \\
\text { the counter: } \\
\text { - Exposure to counterparty risk vastly } \\
\text { increased. } \\
\text { As a consequence, domino-like effects from } \\
\text { one financial institution to another became } \\
\text { likely and potentially catastrophic for the } \\
\text { financial system as a whole. The liquidity } \\
\text { crunch aggravated the problems faced by } \\
\text { counterparties because they found it harder to } \\
\text { meet their contractual obligations. }\end{array}$ \\
\hline \multicolumn{2}{|c|}{$\begin{array}{l}\text { 5. The above factors were fuelled and aggravated by the fragmented regulatory structure } \\
\text { inherited from the 1930s, the practice of regulator-shopping, and the lax enforcement of existing } \\
\text { regulations. In a complex and tightly coupled system, regulators must have: (1) a 360-degree } \\
\text { view of the system to identify problems; and (2) the authority necessary to deal with problems } \\
\text { that could imperil the system. }\end{array}$} \\
\hline
\end{tabular}

